\title{
Studies on the Financial and Economic Effects and Improving Measures of China's Transformation from Business Tax to VAT
}

\author{
Yun $\mathrm{Li}^{1, \mathrm{a}}$ \\ ${ }^{1}$ School of North China Electric Power University, Baoding 071000, China \\ a2712377880@qq.com
}

\begin{abstract}
The business tax is a kind of tax collected by total business turnover derived from the provision of taxable services, the transfer of intangible assets and the sale of immovable property in China, while the value-added tax (VAT) is a kind of turnover tax levied on the increase in the value of goods in production and circulation and the provision of labor services. China's "Transformation from business tax to VAT" is a taxation reform policy, whose essence is to enlarge the range of levying VAT and bring the original industries that pay business tax under the range of levying VAT. It started trial in Shanghai's six service industries since January 1, 2012, and began to implement in all service industries in the nationwide since May 1, 2016. On the one hand, we can see that "Transformation from business tax to VAT" is an important content of China's taxation reform, which has a significant impact on reducing VAT taxation burden of enterprises, reducing fiscal revenue, promoting economic growth, adjusting industrial structure and other aspects. On the other hand, there are difficulties like taxpayer identity selection, tax rate selection, the scope of input tax which can be deducted, and the VAT income distribution between central and local and so on, in the pilot process. This paper analyzed the financial and economic effect of "Transformation from business tax to VAT", and put forward some countermeasures in view of the practical problems arising from the pilot process, so as to perfect the implementation of China's "Transformation from business tax to VAT" and sum up advanced experience for China's follow-up taxation system reform as well as other countries that are committed to reform their taxation system.
\end{abstract}

Keywords: Transformation from business tax to VAT, Financial and economic effect, Taxation system reform

\section{Introduction of Transformation from Business Tax to VAT's Pilot Process}

\subsection{The First Stage: Part of the Service Industry, in Some Areas}

At first, Shanghai City took the lead to implement "Transformation from business tax to VAT" in six industries including the transportation, research and development, information technology, cultural and creative industry, logistics support services, tangible movable property leasing, identification and consultation service since January 1, 2012. And then, the scope of the pilot areas gradually expanded to other 8 provinces and cities like Beijing, Jiangsu, Anhui, Fujian, Guangdong, Tianjin, Zhejiang and Hubei Province, from September 1, 2012 to December 1, 2012.

\subsection{The Second Stage: Part of the Service Industry, Nationwide}

Gradually, the pilot of "Transformation from business tax to VAT" covered the whole country, and the radio and television services industry was brought into the pilot range on August 1, 2013. And then, the railway transport industry and postal services began to implement the pilot of “Transformation from business tax to VAT", nationwide. Since then, all the transport industry was brought into the scope of the pilot industry. Soon, the telecommunications industry in the country started to implement the pilot since June 1, 2014.

\subsection{The Third Stage: All Service Industries, Nationwide}

By of the end of 2015, the taxpayers who were listed in the pilot scope had reached 5.92 million, and the tax reduction amount had reached RMB 641.2 billion Yuan. From May 1, 2016, the scope of the pilot industry gradually expanded to the construction industry, real estate, finance, life services industry and so on. From then on, China began a comprehensive implementation of the 
“Transformation from business tax to VAT", which is an important content of China's taxation reform, promoting China's economic growth, industrial restructure and so on.

\section{Main Content of Transformation from Business Tax to VAT}

(1) Add $6 \%$ and $11 \%$ these two grades of tax rate to the existing tax rate of VAT, keeping the original tax rate of $13 \%$ and $17 \%$.

(2) Provision of movable property leasing services at a VAT rate of $17 \%$; provision of transportation services including land transport services, waterway transport services, air transport services, pipeline transportation services at a VAT rate of $11 \%$; some modern services include R \& D and technical services, information technology services, cultural and creative services, logistics support services, forensic advisory services at a VAT rate of $6 \%$; taxpayers whose annual taxable service sales from provision of transportation and the modern service industries mentioned before, is 5 million Yuan or less shall apply the simple collection method for VAT rate of $3 \%$.

(3) Continue to carry out the original business tax preferential policies.

(4) During the pilot period, the value-added tax income due to "Transformation from business tax to VAT", is still attributable to pilot areas' local government instead of the central, which is compensation for their loss of the original business tax income.

(5) The general taxpayers, who hold special VAT invoices that are issued by the taxpayer in the pilot area, can enjoy VAT deduction according to regulations.

As for choosing which method to calculate the amount of VAT, the general taxpayers shall apply the general tax method, while the small-scale taxpayers shall apply a simple tax method. In principle, the amount of VAT that taxpayers shall pay is calculated by all the income they obtain from the taxable transactions. However, for those industries that exist a large number of collections or payment of funds on behalf of others, the amount of its collection and payment can be reasonably deducted from the tax base. Import trade or services within the taxable scope shall pay value-added tax in domestic links, while export trade or services apply zero tax rate or VAT-free [1].

\section{Financial and Economic Effects of Transformation from Business Tax to VAT}

\subsection{Reducing VAT Taxation Burden of Enterprises}

The direct benefit that "Transformation from business tax to VAT" brings to the pilot enterprises is the reduction of the enterprises' VAT taxation costs. Under VAT system, the more deduction, the less VAT enterprises will pay, so "Transformation from business tax to VAT" can not only avoid the repeated taxation between the pilot industries and the upstream enterprises, which thus reduces the taxation burdens of the service enterprises, but also avoid the repeated taxation between the pilot industries and the downstream enterprises, which thus reduces the taxation burdens of industry chains. By of the end of 2015, the taxpayers who were listed in the pilot scope had reached 5.92 million, and the tax reduction amount had reached RMB 641.2 billion Yuan. "Transformation from business tax to VAT" reduces the taxation burdens of enterprises obviously, accelerates the updating and perfection of enterprises' equipment, and facilitates the improvement of production efficiency, and boost the transformation and upgrading of enterprises.

\subsection{Reducing Fiscal Revenue}

As is mentioned above, "Transformation from business tax to VAT" brings pilot enterprises great reduction of the enterprises' VAT taxation costs, which also means the financial revenue reduction, as tax revenue is the main source of financial revenue [2]. As we can see, pilot areas' tax cuts up to RMB42.68 billion Yuan in 2014, and tax cuts exceeded RMB150 billion Yuan in 2015, combined with the corresponding tax data and online survey data. And it can be seen, the amount of tax cuts will continue to increase tax cuts with the continuous promotion of "Transformation from business tax to VAT". Those all means the corresponding amount of fiscal revenue reduction. However, the current fiscal revenue reduction will stimulate economic growth, having a positive effect for the long-term fiscal revenue increase [3]. 


\subsection{Promoting Economic Growth}

"Transformation from business tax to VAT" promotes economic growth, mainly through the structural tax cuts, optimizing the allocation of resources, promoting investment, consumption and net exports, driving China's GDP growth. On the one hand, the structural tax cuts reducing the overall corporate tax burden is conducive to the survival and development of enterprises and overseas business development, resulting in an expansion effect on productivity. On the other hand, optimizing the allocation of resources promotes the integration of the production resources and the efficiency of resource allocation, as the value-added tax has the advantages of the tax neutral characteristics compared with the sales tax. For the most important, after the implementation of "Transformation from business tax to VAT”, not only service enterprises' input tax from purchasing fuel and equipment, repair service and so on can be deducted, and manufacturing enterprises' special value-added tax invoices can also be deducted, which opens up the value-added tax deductible chain between the secondary industry and tertiary industry, so that resources can flow in industries more reasonably, leading elements of resources concentrate to the advanced industries and enterprises to improve the efficiency of overall allocation of material resources, facilitating China's rapid economic growth.

\subsection{Adjusting Industrial Structure}

"Transformation from business tax to VAT" achieves industrial structural adjustment by promoting structural optimization, upgrading the industrial level, focusing on industrial development on the basis of rationally guiding the division of labor and deepening cooperation, as "Transformation from business tax to VAT" chooses eliminating the repeated taxation of trading goods and offering services, improving the value-added tax deductible chain as the core.

On the one hand, "Transformation from business tax to VAT" plays an important role in promoting the formation of China's new industrial structure whose mainstay is service industry and optimization of economic structure, through avoiding the repeated taxation, reducing the tax burden, creating a better tax environment to speed up the development of the service industry.

On the other hand, "Transformation from business tax to VAT" has the effect of raising the industrial level. From the point of view of practice, the enterprises with high industrial level benefit much more from "Transformation from business tax to VAT" than the enterprises with low industry level, so as to encourage the enterprises to continuously upgrade the industry level, optimizing China's industrial structure as a whole. Moreover, the implementation of the "Transformation from business tax to VAT" is conducive to China's achieving industrial restructuring and enhancing the overall economic efficiency, through attracting multinational corporations to invest in China due to tax incentives.

\section{Improving Measures of China's Transformation from Business Tax to VAT}

(1)Increase the support to operating leasing enterprises to control their tax burden, as their tax cuts are not complete enough. This requires the overcoming of the following two constraints. On the one hand, the small-scale taxpayers' assets are limited to the stock assets purchased before the pilot implementation. That's to say, if the enterprise holds the leasing business through the newly purchased assets, it is still required to pay tax a VAT rate of $17 \%$, which is obviously detrimental to the expansion of the leasing industry. On the other hand, those small-scale taxpayers who apply a simple tax method at a VAT rate of 3\%, lose the chance of entering the VAT deduction chain.

(2)Stipulate the financial leasing enterprises' legal status and tax burden level from the perspective of tax law, to solve the problem of there being differences of tax preferential policies between the upstream and downstream enterprises in financial leasing industry [4]. Specifically, it is recommended that the financial leasing enterprises shall be included in the scope of the VAT taxpayers, dividing them into the general taxpayer and the small-scale taxpayer according to their actual situation. After the expiration of the financial lease, if the lessee who is a general taxpayer purchase leasing equipment, the economic behavior should be identified as purchase behavior, which 
means the lessor shall issue a special VAT invoice to the lessee according to the actual situation of the transaction, so that the lessee can enjoy VAT deduction according to regulations at the same VAT rate as the lessor. In this way, it is conducive to implementing the tax preferential policies in the financial leasing industry.

(3) Control the tax burden of enterprises in the transportation industry. Since some of the taxpayers in the transportation industry have been identified as VAT general taxpayers, whose nominal tax rate has changed from $5 \%$ to $11 \%$, but their corresponding pre-tax deduction has not been able to follow up in time. Thus, they face a substantial increase of tax burden [5]. In view of the situation that some of the taxpayers in the transportation industry hold a number of fixed assets purchased has not been depreciated, taxpayers' input tax of those fixed assets should be deducted according to their remaining useful life, in order to balance the gap between them and other enterprises who can enjoy VAT deduction from lots of newly purchased fixed assets, reducing the tax burden of the transport industry as a whole.

(4) Rationally design VAT tax income distribution system in the central and local financial department [6]. For one thing, Value-added tax is one of the central and local finance to share taxes while the business tax mainly belongs to the local government, which means that the local government will lose their main source of fiscal revenue after the complete implementation of "Transformation from business tax to VAT". Therefore, it significant to set a reasonable allocation of VAT tax income between central and local fiscal department, maintaining the level of local fiscal revenue in order to stabilize the local financial expenditure and promoting their public infrastructure construction and enhancing the level of local economic development.

\section{Conclusion}

As an important content of China's taxation reform, "Transformation from business tax to VAT" has a significant impact on reducing VAT taxation burden of enterprises, reducing fiscal revenue, promoting economic growth, adjusting industrial structure and other aspects. The implementation of the reform in China has created favorable conditions for economic development, and will continue to play its positive financial and economic effects with subsequent improvement measures, providing valuable experience for countries around the world to improve their taxation system.

\section{References}

[1] Shujia Min. Transformation from Business Tax to Value-added Tax's Tax Burden Implications[D]. China University of Mining and Technology, 2015.

[3] Xin Zhang, Tifu An. Analysis of Transformation from Business Tax to VAT's Effect of Reducing Fiscal Revenue [J]. Tax Research, 2013, (10): 9-13.

[4] Jianren Li. The Present Progress of Transformation from Business Tax to VAT and the Future of It [J]. Financial Problems Research, 2013, (05): 78-84.

[5] Yijian Hu, Zhiwei Tian. Financial and Economic Effects of Transformation from Business Tax to Value-added Tax [J]. Tax Research, 2014, (01): 38-43.

[6] Wenxuan Pan. Analysis of the Phenomenon of Part of the Enterprises' Increasing VAT Burden in Pilot Areas [J]. Finance and Trade Research, 2013, (01): 95-100.

[7] Jiechang Xia, Yonghao Guan. Measures to Get Rid of the Present Plight and the Next Step of the Transformation from Business Tax to VAT [J]. Journal of Reform, 2013, (06): 65-72. 